\title{
The Relationship Between Imports and Inflation in Palestine: Toda and Yamamoto Causality Analysis
}

\author{
Sameer Mostafa Abumdallala ${ }^{1}$ \\ ${ }^{1}$ Alazher University, Gaza, Palestine \\ Correspondence: Sameer Abo Mudalla, Head Department of Economics, Alazher University, Gaza, Palestine. \\ Received: December 23, 2018 \\ Accepted: January 11, 2019 \\ Online Published: January 29, 2019 \\ doi:10.5430/ijba.v10n2p17 \\ URL: https://doi.org/10.5430/ijba.v10n2p17
}

\begin{abstract}
The amid of this study empirically analyzes the dynamic relationship between Imports and Inflation in Palestine. The study use daily data from of first quarter on 1996 to fourth quarter 2016. Used the Toda and Yamamoto (1995) causality test.

The study found that the null hypothesis that the All Share INF does not cause the IMP is rejected, while the INF rate does not because IMP is not rejected at 5\% significate level. The study recommended. There is need to decrease the imports for decreasing inflation in Palestine.
\end{abstract}

Keywords: Toda and Yamamoto, inflation, imports

\section{Introduction}

Inflation is one of the major macroeconomic variables and it is defined inflation as a persistent increase in general price level of consumers in a country (Barro, 2008). Furthermore, Barro stated that inflation could also be explained by the purchasing power of the country. That is a continuation drop in the purchasing power.

Economic theory states that inflation and import have positive relationship. For example, an increase in aggregate spending exceeds the local demand that leads to the need for import to meet the local demand. As import, quantity has demanded increase, the price of imported goods and services rise, causing the inflationary pressure to the economy. The lack of sufficient resources for production in many developing African countries has led to a dependency on import for consumption (Ogbokor \& Sunde 2011; Islam, 2013).

In economic Palestine, was depend at imports. Otherwise, The Palestine Monetary Authority (PMA) confirmed that inflation is imported. Thus, there is an impact on inflation in Palestine. The study therefore focused on the causal relationship between imports and inflation. In order to achieve the objective of the study, so was divided the paper as follows: the next section presents a literature review. Section 3 discusses the methodology. Section 4 concludes the study.

\section{Literature Review}

Over Many years there are many studies conducted about the relationship between Imports and inflation. Several studies address the importance of imports inflation. The findings of these studies indicate that imports have a statistically significant impact inflation. We can summarize some of the studies that have addressed the issue of effect imports on inflation as follows:

The study (Zombe\& et al) examines whether a significant relationship exists between inflation and trade openness in Zambia over the period 1985 to 2015 . The study used the Toda-Yamamoto approach to Granger causality to test for a causal relationship between inflation and trade openness. The results establish a bi-directional causality between inflation and trade openness.

The study (Munepapa, Sheefeni, 2017) examined the impact of imports on inflation in Namibia using quarterly data from the period 1991Q1 to 2013Q4. The model estimated used imports as a dependent variable, while gross domestic product, money supply (M2), lending rate, and exchange rate as the explanatory variables. An error correction modelling approach was applied on the double log functional form in order to investigate the significance and effect of explanatory variables to inflation in Namibia. The results for the unit root test showed that all the variables were stationary in first difference. The residual based test to cointegration revealed that there is cointegration among the 
variables. The error correction model showed that imports have a positive effect on inflation in the long run while in the short run the effect is insignificant.

Study -Al-Mukit (2013) investigated the relationship between inflation and import for the economy of Bangladesh over the sample period of 2000 to 2011. This study used different econometric techniques of measuring the long and short-term relationship between variables. The Johansen Cointegration test is used to determine the existence of long-term relationships between study variables. The normalized Cointegration coefficients are found statistically significant and show a stable and positive relationship between study variables. The short run interactions are similar to the long run relationships. The estimated error correction coefficient indicates that 0.6 percent deviation of the inflation rate from its long run equilibrium level is corrected each period where such correction rate for import is 24 percent. Finally, Granger causality analysis suggests the existence of a unidirectional causality running from Inflation to import.

Study Kalaitzi (2013) examined the relationship between exports and economic growth in the United Arab Emirates over the period 1980-2010. The study applied the two-step Engle-Granger cointegration test and the Johansen cointegration technique in order to confirm or not the existence of a long-run relationship between the variables. Moreover, this study applied a Vector Autoregression Model in order to construct the Impulse Response Function and the Granger causality test to examine the causality between exports and economic growth. The findings of this study confirmed the existence of a long-run relationship between manufactured exports, primary exports and economic growth. In addition, the Granger causality test showed unidirectional causality between manufactured exports and economic growth. Thus, further increase in the degree of export diversification from oil could accelerate economic growth in UAE.

(Ulke\& ERG-N, 2011) investigated the relationship between inflation and import volume by using monthly time series data for the Turkish economy over the period 1995-2010. The study applies a number of econometric techniques: Augmented Dickey-Fuller unit root test, univariate cointegration test, error correction model, and Granger causality test. The results of this dissertation show that there is long term and short term co-integration relation between inflation and import volume. Indeed, there is one-way Granger-causality from import to inflation.

Sangho \& others (2007) investigated the effect of imports and exports on total factor productivity in Korea during 1980-2003. We find Granger causality from imports to total factor productivity (TFP) growth, but no causality from exports to TFP growth. We then investigate the impact of trade and other variables on TFP growth. According to our results, imports have a significant positive effect on TFP growth but exports do not.

Study (Musabeh, 2006) measured the effect of several economic variables on inflation in Syria, by using cointegration and causality tests as a method. The variables are specify depending on the economic literature that has treated this field, this study concludes that there is a long run effect between the inflation determinants (economic deflation indicators and the monetary policy indicator) and the inflation in Syria. In addition, there are long and short run causality relations runs from the inflation determinants into inflation indicator (CPI).

\section{Research Methodology}

This study intends to examine the dynamic relationship between Imports and Inflation in Palestine. It uses quarterly observation of data (from 02nd of first quarter on 1996 to fourth quarter 2016. After adjust the national holidays of the country, the sample of this study includes (78) observations in total. The relevant data are obtained from Palestinian Central Bureau of Statistics online database. Finally, all time series data are transformed into natural logarithm form for the statistical purpose. The time series variables must be stationary in order to obtain meaningful results in most time series statistical analysis. The mean and variance of a stationary time series variables do not change over Time (Gujarati, 1974). Granger and Newbold(Granger,1974) have shown that even though the studies with non-stationary time series data the results having high R2 175 and significant t statistic values, the estimated factors and results are not economically meaningful. Therefore, studies associated with time series data, it is necessary to test the stationary of the series to avoid incorrect interpretations and inferences. Therefore, the Augmented Dickey-Fuller (ADF), Phillips-Perron (PP) and Kwiatkowski-Phillips- Schmidt-Shin (KPPS) test statistics are used to determine the stationary of data. If the variables become stationary after convert into the same order of deference, i.e. both variables 1 are integrated of order one; then it is to be tested for the existence of a co-integration relationship between the variables. The co-integration test is done among the variables using the Johansen (Johansen, 1988) Co-integration tests. Since, Johansen co-integration is sensitive to the lag length the Final prediction error (FPE), Akaike information criterion (AIC), Schwarz information criterion (SC) and Hannan-Quinn information criterion (HQ) are used to determine the appropriate lag length. The Johansen Integration test is performed to test the existence of the long-term relationship between the variables. 
If there is any evidence for the existence of any long-run relationship between the variables, then need to perform the VECM to test the causal relationship between the variables in the long run. If not, then need to test for the existence of the short-term causal relationship between the variables. The Granger causality test, which is widely used in the literature to examine the causal relationship among variables in the short-run. In order to perform the Granger causality test, the data series must be stationary even at their level or different levels. Even though many statistical analyses use the Pairwise Granger Causality tests, it has some statistical limitations. Consequently, Toda and Yamamoto have introduced an improved model to assess the causal 194 relationship among variables. Therefore, the Toda-Yamamoto causality test is then used to provide better explanations of the relationship between the variables. It is essential to determine the lag length $(\mathrm{k})$ and the maximum order of integration (dmax) of the series to perform the Toda-Yamamato causality test. Once these two values have been determined, the Toda-Yamamato test can be performed by constructing Vector Autoregression (VAR) model of ( $\mathrm{k}+\mathrm{dmax}$ ) size (Yamamoto, 1995).

\section{Results \& Discussion}

\subsection{Unit Root Test}

In order to examine the dynamic relationship between the variables, it needs to make sure that the data series are stationary. For this, unit root test is performed by using the Augmented Dickey-Fuller, Phillips-Perron and Kwiatkowski-Phillips-Schmidt-Shin test statistics. This test statistics are used to test whether the time series variables contained a unit root.

Table 1. Unit Root Test

\begin{tabular}{ccccc}
\hline & $\begin{array}{c}\text { Augmented Dickey-Fuller } \\
\text { test statistic }\end{array}$ & $\begin{array}{c}\text { Phillips-Perron } \\
\text { test statistic }\end{array}$ & $\begin{array}{c}\text { Kwiatkowski-Phillips-Schmidt- } \\
\text { Shin test statistics }\end{array}$ \\
\hline \multirow{2}{*}{ INF } & Level & $*-7.144545$ & $*-6.830087$ & $* 0.578543$ \\
& 1st Difference & $*-10.09782$ & $*-25.72602$ & $* 0.116962$ \\
\multirow{2}{*}{ IMP } & Level & $-\mathbf{0 . 1 1 7 9 5 6}$ & $-\mathbf{0 . 9 5 6 1 7 3}$ & $\mathbf{0 . 9 9 9 3 0 7}$ \\
& 1st Difference & $*-10.29455$ & $*-12.29128$ & $* 0.50000$ \\
\hline
\end{tabular}

* denotes rejection of the hypothesis at the 0.05 level

We can show from table 1 the unit root test results for the unit root test., the unit root test result of the variables at the $1 \%$ level of significance reveals the inflation variables have unit root at their level, but imports become stationary after convert to the 1 st difference. Therefore, both data series are cointegrated of order one I (1).

\subsection{Johansen Cointegration Test}

Since all variables are integrated with order one, i.e. I (1), the Johansen cointegration, test can be applied, cointegration implies existence of long-run equilibrium relationship; thus help predict stable, Granger (1986) testing for cointegration helps to avoid spurious regression. Non-stationary variables can lead to spurious regression unless at least one cointegrating vector is present (Nowbutsing, Ramsohok and Ramsohok, 2010), the following table shows the results of a test of the integrity of the joint Johansson (Brooks, 2008).

Table 2. Co-integration test

\begin{tabular}{ccccccccc}
\hline & \multicolumn{3}{c}{ Test (Trace) } & \multicolumn{4}{c}{ Test (Maximum Eigenvalue) } \\
\hline Hypothesize & Eigenvalue & \multicolumn{3}{c}{ Eigenvalue } & & & \\
D No.of & & Trace & 0.05 & Prob.** & & Trace & 0.05 & Prob.** \\
CE(s) & & Statistic & Critical Value & & & Statistic & Critical Value & \\
None & 0.355254 & 49.81632 & 15.49471 & 0.0000 & 0.355254 & 34.23408 & 14.26460 & 0.0000 \\
At most 1 & 0.181083 & 15.58224 & 3.841466 & 0.0001 & 0.181083 & 15.58224 & 3.841466 & 0.0001 \\
\hline
\end{tabular}

Trace test indicates no cointegration at the 0.05 level

* denotes rejection of the hypothesis at the 0.05 level

**MacKinnon-Haug-Michelis (1999) p-values

Since both variables are cointegrated, it indicates the existence of a long-run relationship between the variables. 
Therefore, to test the existence of long-run relationship, the Johansen co-integration test is applied which uses a trace test and a maximum Eigen value. From Table 2 the result indicates that there is no integration equations in the given variables. Therefore, it suggests that there is cointegrating relationship between imports and inflation in Palestine. As such, the VECM (Vector Error Correction Model) can be applied to test the existence of the causal relationship between the variables in the long run.

Table 3. VAR lag order selection criteria

\begin{tabular}{ccccccc}
\hline lag & Logl & LR & FPE & AIC & SC & HQ \\
\hline 0 & -1186.731 & NA & $1.32 \mathrm{e}+11$ & 31.28239 & 31.34373 & 31.30691 \\
1 & -1084.636 & 196.1307 & $9.99 \mathrm{e}+09$ & 28.70094 & 28.88494 & 28.77447 \\
2 & -1075.057 & 17.89619 & $8.63 \mathrm{e}+09$ & 2855414 & $28.86982^{*}$ & 28.67670 \\
3 & -1067.341 & $14.01093^{*}$ & $7.83 \mathrm{e}+09^{*}$ & $28.45635^{*}$ & 28.88569 & $28.62793^{*}$ \\
4 & -1065.905 & 2.532895 & $8.39 \mathrm{e}+09$ & 28.52380 & 29.07582 & 28.74442 \\
5 & -1602.291 & 6.180417 & $8.49 \mathrm{e}+09$ & 28.53398 & 29.20867 & 28.80362 \\
6 & 1059.639 & 4.396650 & $8.82 \mathrm{e}+09$ & 28.56946 & 29.36682 & 28.88812 \\
7 & -1057.589 & 3.292230 & $9.32 \mathrm{e}+09$ & 28.62077 & 29.54080 & 28.988846 \\
8 & -1053.700 & 6.038324 & $9.39 \mathrm{e}+09$ & 28.62369 & 29.66639 & 29.04040 \\
\hline
\end{tabular}

* indicates lag order selected by the criterion

LR: sequential modified LR test statistic (each test at 5\% level)

FPE: Final prediction error

AIC: Akaike information criterion

SC: Schwarz information criterion

HQ: Hannan-Quinn information criterion

In order to perform the Toda and Yamamoto [24] test, it needs to determine the appropriate lag length (p) with the help of the VAR model. Then, the maximum degree of smoothing (dmax) is added to the lag length (p). In this case, the relevant VAR model can be written in the equations as follows.

$$
\begin{aligned}
& I M P_{t}=\alpha_{0}+\sum_{t-i}^{K+d_{\max }} \alpha_{2} I M P_{t-i}+\sum_{t-i}^{K+d_{\max }} \beta_{2} I N F_{t-i}+\varepsilon_{t} \\
& I N F_{t}=\alpha_{0}+\sum_{t-i}^{K+d_{\max }} \alpha_{2} I N F_{t-i}+\sum_{t-i}^{K+d_{\max }} \beta_{2} I M P_{t-i}+\varepsilon_{t}
\end{aligned}
$$

Equation (1)

Equation (2)

According to the results obtained from the VAR model is shown in Table 3, it was found that the optimal lag is 2 . Therefore, it has been decided that the number of "p" lag is 6 . Because of the unit root tests obtained in Table 2, it is seen that the IMP and INF integrated at I (1). In this way, it is decided that the highest degree of integration of the series (dmax) is 1 . Therefore, the Toda-Yamamoto causality analysis requires for adjusted VAR model is $\mathrm{p}+\mathrm{dmax}$ is three. The results obtained Toda-Yamamoto causality analysis are reported in Table 4.

Table 4. Toda-Yamamoto causality test

\begin{tabular}{llll}
\hline Null Hypothesis & Chi-Sq & df & prob \\
\hline IMP Rate does not Granger Cause INF & 6.224065 & 2 & $0.0445^{*}$ \\
INF Rate does not Granger Cause IMP & 4.632035 & 2 & 0.0987 \\
\hline
\end{tabular}

* denotes rejection of the hypothesis at the 0.05 level

The Toda-Yamamoto causality analysis result is given in Table 4. The table provided Chi-square statistic and probability values with respect to the null hypothesis of non-causality. The test result reveals that the null hypothesis 
that the All Share INF does not cause the IMP is rejected, while the INF rate does not because IMP is not rejected at 5\% significate level. Therefore, it suggests that there is one-way causal relationship from All Share IMP to INF in Palestine. The Palestinian Monetary Authority confirmed that inflation in Palestine is due to imported inflation (Palestinian Monetary Authority, 2010)

\section{Conclusion and Policy Recommendations}

The study aimed to empirically analyzes the dynamic relationship between Imports and Inflation in Palestine. The study used daily data from of first quarter on 1996 to fourth quarter 2016, using the Toda and Yamamoto (1995) causality test.

The study recommends the following policy measures for the economic growth in Palestine. As long as the gross capital formation plays a key role in economic growth in the Palestine, Palestine must encourage increase in gross capital formation, to increase its contribution to economic growth. Support for growth-led export in Palestine Thus effort should be direct towards policies that will enhance economic growth such as industrialization, in order to affect more on exports, the need to approach the Palestine, to economic openness to enhance the role of exports and imports in the economic growth policy. In addition, Palestine need to focus on vocational education, through the holding of professional training courses, because of its important role in raising the productivity of the worker in Arab countries. It is important indicator for measuring the efficiency and effectiveness of the work element in achieving a certain level of the output in the production process. There is need to decrease the imports for decreasing inflation in the Palestine.

\section{References}

Al-Mukit, D., Shafiullah, A.Z.M \& Ahmed, Md.R. (2013). Inflation Led Import or Import Led Inflation: Evidence from Bangladesh. Asian Business Review, 2(4).

Barro, R.J. (2008). Macroeconomics: A Modern Approach. Mason: Thomson Corporation.

Brooks, C. (2008). Introductory econometrics for finance (2nd ed.). Cambridge University, New York.

Cheng, M., \& Tan, H. (2002). Inflation in Malaysia. International Journal of Social Economics, 29, 411-425.

Granger, C.W., \& Newbold, P. (1974). Spurious regressions in econometrics. Journal of Econometric, 2, 111-120. https://doi.org/10.1016/0304-4076(74)90034-7

Gujarati, D.N., \& Porter, D.C. (1999). Essentials of econometrics. Irwin/McGraw-Hill Singapore.

Johansen, S. (1988). Statistical analysis of cointegration vectors. Journal of Economic Dynamics and Control, 12 , 231-254. https://doi.org/10.1016/0165-1889(88)90041-3

Kalaitzi, A. (2013). Exports and Economic Growth in the United Arab Emirates, Submitted to: RIBM Doctoral Symposium, Manchester Metropolitan University Business School.

Munepapa, M., \& Sheefeni, J. (2017). The Impact Of Import On Inflation In Namibia. European Journal of Business, Economics and Accountancy, 5(2).

Musabeh, E. (2006). Determinants of Inflation in Syria during the Period 1970-2004. Journal of Social Sciences. Kuwait University, Scientific Publishing Council.

Ogbokor, C.A., \& Sunde, T. (2011). Is Namibia's Inflation Import-Driven?. An Econometric Investigation. Journal of Development Alternatives and Areas Studies, 30, 1-12.

Palestinian Monetary Authority. (2010). Inflation Report, Research and Monetary Policy Department. Palestine.

Sangho, H., \& Donghyun. (2007). The Effect of Imports and Exports on Total Factor Productivity in Korea. The Research Institute of Economy, Trade and Industry. Retrieved from http://www.rieti.go.jp/en

Toda, H.Y., \& Yamamoto, T. (1995). Statistical inference in vector autoregressions with possibly 320 integrated processes. Journal of Econometrics, 66, 225-250. https://doi.org/10.1016/0304-4076(94)01616-8

Ulke, V., \& Erg-N, U. (2011). Econometric Analysis of Import and Inflation Relationship in Turkey between 1995 and 2010. Journal of Economic and Social Studies, 1(2).

Zombe, Chibvalo at el. (2017, November). Investigating the Causal Relationship between Inflation and Trade Openness using Toda-Yamamoto Approach: Evidence from Zambia. Mediterranean Journal of Social Sciences, $8(6)$. 